\title{
Risk Assessment of Floor Water Inrush in Deep Mine Based on Grey System Theory
}

\author{
LIU Weitao PAN Xiaofeng LIU Huan SHEN Jianjun \\ College of Mining and Safety Engineering, Shandong University of Science and \\ Technology, Qingdao 266590, China
}

\begin{abstract}
In the paper, the comprehensive research was composed of main controlling factors of floor water inrush in deep mine, method of floor water inrush risk assessment and risk assessment system, which was carried on three aspects of the deep seam mining floor water inrush factors analysis, the mathematical model establishment and system programming, based on the Grey system theory. Using the investigation, data assessment, statistical analysis and numerical analysis method, it got the influent factors of floor water inrush in deep mine; By the analytic hierarchy process (AHP), it determined the main controlling factors and their weights. It also determined the accuracy of the main controlling factors and verified their weights of these factors by the Grey relevance analysis. It set up deep mine's floor water inrush risk assessment model through the establishment of membership and the membership function of each main controlling factors deal with information data, according to the Grey matter-element model. And it was tested by practical engineering samples to gain the reliability degree of the established model, which can provide guidance and basis for mining safety.
\end{abstract}

Keywords: deep mine; floor water inrush; Grey system theory; risk assessment

\section{Introduction}

Gradually to the deep coal mining in our country development, water inrush issues occurring in the process of deep coal mining as the major hidden danger of the mine safety production. In order to predict floor water inrush effectively, and guide the mine safety.

\section{Determine the main controlling factors of floor water inrush in deep mine}

This paper analyzed the main controlling factors of floor water inrush in deep mine from five aspects: hydrogeology, water structure, floor water-resisting layer, mining conditions and the characteristics of deep mine. Then we obtain the main impact indicators: water pressure of aquifer, watery of aquifer, the degree of strong water supply, fault hydraulic conductivity, fracture development situation, thickness of water-resisting layer, water-resisting layer lithology combination, floor stress state, mining thickness, mining depth, slant distance of working face, working face advancing distance, characteristics of deep mine(three "high" and one "disturbance"), etc. 


\subsection{Weights determination of floor water inrush influence factors in deep mine based on analytic hierarchy process}

Through the analysis of the factors affecting floor water inrush in deep mine, then establish a index system of deep mine's floor water inrush ${ }^{[6]}$ (Fig.1). According to the structure at all levels of judgment matrix, consulting experts in the field of water inrush prevention, in combination with 1 to 9 scaling method, by comparing two factors to determine the weight value of various influencing factors(Table 1).

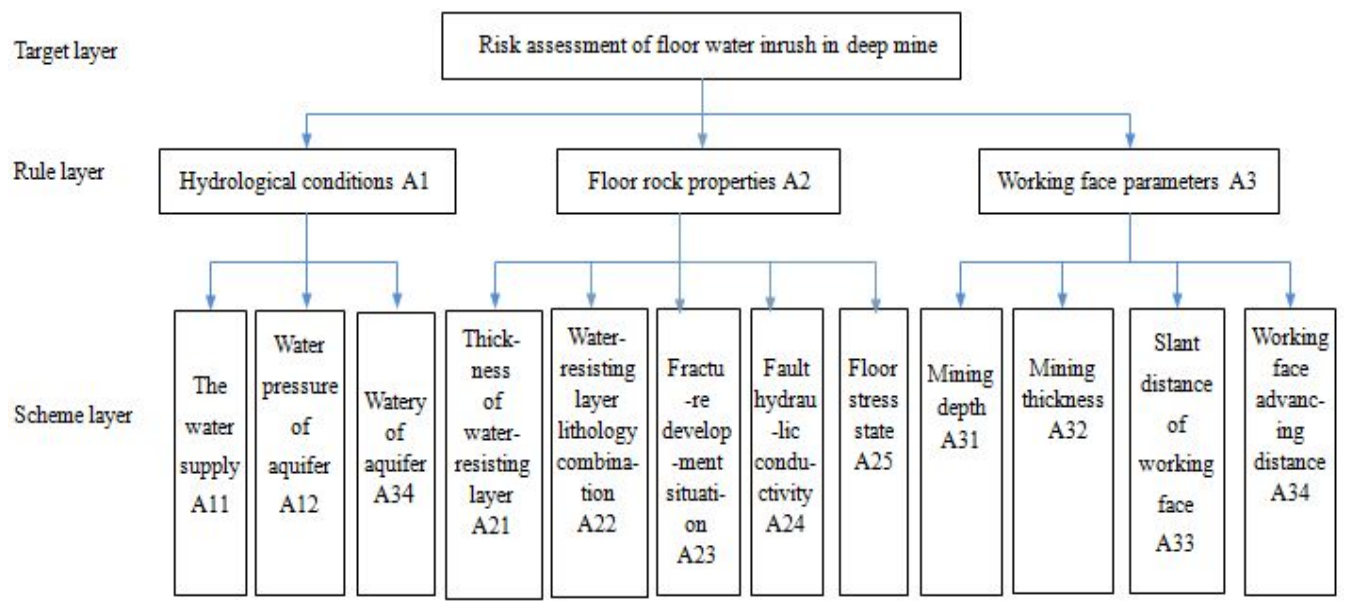

Fig. 1 Hierarchical analysis model of deep mine water inrush risk assessment

Table 1 Total collation of each factor weight

\begin{tabular}{cccccc}
\hline factors & $\begin{array}{c}\mathrm{A}_{1} \\
\omega=1 / 3\end{array}$ & $\begin{array}{c}\mathrm{A}_{2} \\
\omega=4 / 9\end{array}$ & $\mathrm{~A}_{3}$ & weight & rank \\
\hline $\mathrm{A}_{11}$ & $5 / 22$ & 0 & 0 & 0.0758 & 6 \\
$\mathrm{~A}_{12}$ & $9 / 22$ & 0 & 0 & 0.1394 & 1 \\
$\mathrm{~A}_{13}$ & $6 / 22$ & 0 & 0 & 0.1182 & 2 \\
$\mathrm{~A}_{21}$ & 0 & $9 / 35$ & 0 & 0.1092 & 3 \\
$\mathrm{~A}_{22}$ & 0 & $1 / 7$ & 0 & 0.0610 & 9 \\
$\mathrm{~A}_{23}$ & 0 & $1 / 5$ & 0 & 0.0737 & 8 \\
$\mathrm{~A}_{24}$ & 0 & $8 / 35$ & 0 & 0.1041 & 4 \\
$\mathrm{~A}_{25}$ & 0 & $6 / 35$ & 0 & 0.0965 & 5 \\
$\mathrm{~A}_{31}$ & 0 & 0 & $4 / 13$ & 0.0752 & 7 \\
$\mathrm{~A}_{32}$ & 0 & 0 & $3 / 13$ & 0.0496 & 11 \\
$\mathrm{~A}_{33}$ & 0 & 0 & $7 / 26$ & 0.0530 & 10 \\
$\mathrm{~A}_{34}$ & 0 & 0 & $5 / 26$ & 0.0444 & 12 \\
\hline
\end{tabular}

Check the consistency of the above results, the total order inconsistent degree as well as within the scope of the permit, meet the requirements of consistency. Through the above calculation results

show that water pressure of aquifer, watery of aquifer, thickness of water-resisting layer, fault hydraulic conductivity, mining depth and floor stress state are the six main factors of floor water inrush in deep mine. The sum of the weights of several factors is 0.6426 , accounts for $64.26 \%$ of all factors. The result is basically consistent with technical data of the query and past research results.

\subsection{Grey correlation analysis to select main control factors}

Take $\quad X_{\mathrm{i}}=\left[\quad X_{\mathrm{i}}(1), \quad X_{\mathrm{i}}(2), \quad X_{\mathrm{i}}(2)\right.$, $\left.X_{\mathrm{i}}(2)\right]=$ [Possibility of water inrush, Cycle strength, Disaster level, Control measures as various influencing factors correlation 
intensity index of deep mine's floor water inrush to analysis grey correlation. According to reference [7], the four indexes of specific quantitative calibration as shown in table 2 to 5 .

\begin{tabular}{cc}
\multicolumn{2}{c}{ Table 2 Score of the water inrush possibility } \\
\hline Possibility of water inrush & value \\
\hline Actually impossible & 0.1 \\
Extremely impossible & 0.2 \\
Can assume that ,but highly & 0.5 \\
impossible & 1 \\
Less likely & 3 \\
Not often, but possible & 6 \\
Quite likely & 10 \\
Expected completely &
\end{tabular}

Table 3 Score of the cycle appearance

\begin{tabular}{cc}
\hline Cycle strength & value \\
\hline Rarely appeared & 0.5 \\
Seldom appeared & 1 \\
Once a step away from the show & 3 \\
Step away from the show many & 6 \\
times & 10 \\
Show all the time & \\
\hline
\end{tabular}

Table 4 Score of control measure

\begin{tabular}{cc}
\hline Control measure & value \\
\hline Prediction measures & 1 \\
Emergency measures & 3 \\
Without any measures & 5 \\
\hline
\end{tabular}

Table 5 Score of the disaster level

\begin{tabular}{cc}
\hline Disaster level & value \\
\hline No harm & 1 \\
Minor injuries & 3 \\
Seriously injuries & 7 \\
One person died & 15 \\
Less than five people died & 40 \\
More than five people died & 100 \\
\hline
\end{tabular}

The parameters of the various influencing factors of floor water inrush in deep mine is composed of four related indexes quantitative score. Reference sequence is composed of the optimal value of each related indexes. According to the following formula, various factors affecting the correlation can be obtained, as shown in table 6 .

$$
\begin{aligned}
& \xi_{i}(n)=\frac{\triangleright_{\min }+\rho \triangleright_{\max }}{\triangleright_{i}(n)+\rho \triangleright_{\max }}, n=1,2,3,4 ; i=1,2 \cdot n \\
& \gamma_{i}=\frac{1}{n} \sum_{k=1}^{n} \xi_{i}(k)
\end{aligned}
$$

\begin{tabular}{|c|c|c|}
\hline Influence factors & correlation & sorting \\
\hline Water pressure of aquifer & 0.6456 & 2 \\
\hline Watery of aquifer & 0.6194 & 1 \\
\hline $\begin{array}{l}\text { The degree of water } \\
\text { supply }\end{array}$ & 0.8111 & 9 \\
\hline $\begin{array}{c}\text { Thickness of } \\
\text { water-resisting layer }\end{array}$ & 0.6700 & 3 \\
\hline $\begin{array}{l}\text { Water-resisting layer } \\
\text { lithology combination }\end{array}$ & 0.8333 & 12 \\
\hline $\begin{array}{l}\text { Fracture development } \\
\text { situation }\end{array}$ & 0.8310 & 11 \\
\hline $\begin{array}{l}\text { Fault hydraulic } \\
\text { conductivity }\end{array}$ & 0.7022 & 4 \\
\hline Floor stress state & 0.7189 & 5 \\
\hline Mining depth & 0.7251 & 6 \\
\hline Mining thickness & 0.8211 & 10 \\
\hline $\begin{array}{c}\text { Slant distance of working } \\
\text { face }\end{array}$ & 0.7570 & 8 \\
\hline $\begin{array}{l}\text { Working face advancing } \\
\text { distance }\end{array}$ & 0.7444 & 7 \\
\hline
\end{tabular}

Table 6 Correlation and sorting of each factor

As the results show that water pressure of aquifer, watery of aquifer, thickness of water-resisting layer, fault hydraulic conductivity, mining depth and floor stress state are the main controlling factors of floor water inrush in deep mine. Results are the same by using grey correlation analysis to select the main controlling factors and using the analytic hierarchy process to select the main controlling factors. Therefore, we can conclusion that choose the above six 
factors for risk assessment of floor water

\section{Risk assessment of floor water inrush in deep mine}

\subsection{Establish a membership function}

In order to analysis and evaluation effectively, when we assess the risk of floor water inrush in deep mine, The order of water pressure of aquifer, thickness of water-resisting layer, floor stress state, mining depth, watery of aquifer and fault hydraulic conductivity membership function are as follows:

$$
P=\left\{\begin{array}{cc}
0 & p \leq 2 M P a \\
\frac{p-2}{8} & 2 M P a \leq p \leq 10 M P a \\
1 & p \geq 10 M P a
\end{array}\right.
$$

Table 7 Watery of aquifer to the water inrush membership function

\begin{tabular}{lcrrrl}
\hline Water level & $\begin{array}{l}\text { very } \\
\text { poor }\end{array}$ & \multicolumn{2}{c}{ poor general well } & $\begin{array}{l}\text { very } \\
\text { well }\end{array}$ \\
\hline membership & 0.1 & 0.3 & 0.5 & 0.7 & 0.9 \\
\hline
\end{tabular}

\subsection{Adjust the main controlling} factors' weights

Table 9 Main controlling factors adjustment weight inrush in deep mine is applicable.

$$
H=\left\{\begin{array}{rlrl}
1 & h & \leq 10 m \\
1-\frac{h}{90} & 10 m & \leq h \leq 100 m \\
0 & h & \geq 100 m
\end{array}\right.
$$

$$
F=\left\{\begin{array}{cc}
0 & t \leq 0.5 \\
\frac{t-0.5}{1.5} & 0.5 \leq t \leq 2 \\
1 & t \geq 2
\end{array}\right.
$$

$$
D=\left\{\begin{array}{rc}
0 & d \leq 600 m \\
\frac{d-600}{400} & 600 m \leq d \leq 1000 m \\
1 & d \geq 1000 m
\end{array}\right.
$$

Table 8 Fault hydraulic conductivity to the water inrush membership function

\begin{tabular}{lcccrr}
\hline $\begin{array}{l}\text { Fault hydraulic very } \\
\text { conductivity }\end{array}$ & \multicolumn{3}{c}{$\begin{array}{c}\text { poor } \\
\text { poneral well }\end{array}$} & $\begin{array}{r}\text { very } \\
\text { well }\end{array}$ \\
\hline membership & 0.1 & 0.3 & 0.5 & 0.7 & 0.9 \\
\hline
\end{tabular}

The main controlling factors are shown in table 9.

\begin{tabular}{lcc}
\hline $\begin{array}{c}\text { Main controlling } \\
\text { factors }\end{array}$ & $\begin{array}{c}\text { water pressure } \\
\text { of aquifer }\end{array}$ & $\begin{array}{c}\text { watery of } \\
\text { aquifer }\end{array}$ \\
\hline $\begin{array}{c}\text { Initial weights } \\
\text { Adjusting } \\
\text { weights }\end{array}$ & 0.1394 & 0.1182 \\
\hline & 0.2169 & 0.1839 \\
3.3 Assess the risk of floor water inrush \\
in deep mine
\end{tabular}

This paper selects five main controlling factors' indicators of deep mining actually(Table 10). Taking an example of this engineering sample, explain the process of water inrush risk assessment in deep mine.

\begin{tabular}{cccc}
$\begin{array}{c}\text { hickness of } \\
\begin{array}{c}\text { ater-resisting } \\
\text { layer }\end{array}\end{array}$ & $\begin{array}{c}\text { fault hydraulic } \\
\text { conductivity }\end{array}$ & $\begin{array}{c}\text { floor } \\
\text { stress state }\end{array}$ & $\begin{array}{c}\text { mining } \\
\text { depth }\end{array}$ \\
0.1092 & 0.1041 & 0.0965 & 0.0752 \\
0.1699 & 0.1620 & 0.1502 & 0.1170 \\
\hline
\end{tabular}

According to correlation degree matter-element matrix, the order of safety degree about these five engineering samples are as follows: sample $2>$ sample $5>$ sample $4>$ sample $3>$ sample 1. Sample 1 is the highest relative risk engineering, sample 2 is relatively the highest degree of safety engineering, predicted results are in conformity with the engineering practice. Sample 2 has no water inrush, the biggest water inrush 
quantity of sample 5 is $4.53 \mathrm{~m} 3 / \mathrm{min}$, the biggest water inrush quantity of sample 4 is $6.3 \mathrm{~m} 3 / \mathrm{min}$, the biggest water inrush quantity of sample 1 is $30 \mathrm{~m} 3 / \mathrm{min}$.

Table 10 Engineering samples

\begin{tabular}{|c|c|c|c|c|c|c|}
\hline $\begin{array}{l}\text { Main controlling } \\
\text { factors } \\
\text { field }\end{array}$ & $\begin{array}{l}\text { water } \\
\text { pressure of } \\
\text { aquifer } \\
/ \mathrm{MPa}\end{array}$ & $\begin{array}{c}\text { watery of } \\
\text { aquifer }\end{array}$ & $\begin{array}{c}\text { thickness of } \\
\text { water-resisting } \\
\text { layer } \\
/ \mathrm{m}\end{array}$ & $\begin{array}{c}\text { fault } \\
\text { hydraulic } \\
\text { conductivity }\end{array}$ & $\begin{array}{c}\text { floor stress } \\
\text { state }\end{array}$ & $\begin{array}{c}\text { mining } \\
\text { depth } \\
/ m\end{array}$ \\
\hline Liang Zhuang51302 & 10 & very well & 28 & very well & 1.9 & 1000 \\
\hline Xie Zhuang3414 & 4 & well & 20 & general & 2.4 & 800 \\
\hline Sun Cun41119 & 7 & well & 15 & very well & 2 & 920 \\
\hline Xia Zhuang1113 & 8 & well & 22 & well & 3 & 900 \\
\hline Zhao Ge-zhuang2137 & 10 & very well & 24 & general & 2.1 & 850 \\
\hline
\end{tabular}

According to correlation degree matter-element matrix, the order of safety degree about these five engineering samples are as follows: sample $2>$ sample $5>$ sample $4>$ sample $3>$ sample 1. Sample 1 is the highest relative risk engineering, sample 2 is relatively the highest degree of safety engineering, predicted results are in conformity with the engineering practice. Sample 2 has no water inrush, the biggest water inrush quantity of sample 5 is $4.53 \mathrm{~m}^{3} / \mathrm{min}$, the biggest water inrush quantity of sample 4 is $6.3 \mathrm{~m}^{3} / \mathrm{min}$, the biggest water inrush quantity of sample 1 is $30 \mathrm{~m}^{3} / \mathrm{min}$.

\subsection{Analysis of the risk assessment results of engineering samples}

Determining the partition threshold of the risk assessment in deep water inrush based on the engineering application of gray matter element model: while $k \leqslant 0.7$, the risk bursting large-scale or super-huge type water inrush in the coal face, which is the danger zone of floor water inrush in deep mine; while $0.7<k \leqslant 0.9$, the working face which is a vulnerable area of the floor water inrush in deep mine occurs small or medium water inrush, which can be changed by improving the safety potential; while $k \geqslant 0.9$, the face is a safe area of the floor water inrush in deep mine.

\section{Conclusions}

(1)Combining the Chromatographic analysis method and gray correlation analysis, it select and validate six controlling factors of the floor water inrush in deep mine, including the water pressure of aquifer, the rich water of aquifer, the thickness of water-resisting layer, fault hydraulic conductivity, mining depth and the stress state of bottom plate, and determine the corresponding weight of each factor, which is more scientific and reliable.

(2)By building membership function of each main controlling factor, and using the gray matter-element model, the risk of floor water inrush in deep mine was evaluated, and compared to the previous established risk assessment or forecasting methods, this risk assessment method with more accurate predictions, easier to use, can achieve dynamic risk assessment 
of the floor water inrush in deep mine.

\section{Acknowledgements}

This work is financially supported by the National Natural Science Foundation of China (Grant No. 51274135); Award fund for excellent young and middle aged scientists of Shandong Province (Grant No.BS2011SF016); the Major Program of the National Natural Science Foundation of China (Grant No. 51034003).

\section{References}

[1] LIU Weitao, CAO Guangquan, and SHEN Jianjun, "Field measurement and simulation research on floor failure depth", Journal of Liaoning Technical University ( Natural Science) , pp.1585-1589,2013.

[2] SHI Longqing, "Summary of Research on Mechanism of Water-inrush from Seam Floor", Journal of Shandong University of Science and Technology ( Natural Science ), pp.17-22,2009.
[3] ZHANG Yanhong, SUN Xiaoguang, "Coal floor water inrush prediction and prevention", Shanxi Coal, pp.73-75,2008.

[4] LIAO Wei, ZHOU Rongyi, and LI Shuqing, "Study on the Non-linear Forecast Methods for Water Inrush from Coal Floor Based on Wavelet Neural Network", China Safety Science Journal, pp.24-28,2008.

[5] The coal industry of coal science research institute of xi 'an branch, "North China type coal field the ash karst safety mining with water pressure supporting technology (\#3)", pp.20-32,1995.

[6] LIU Weitao, SONG Chuanwen, and ZHANG Guoyu, "Predicting and Evaluating of Floor Water Inrush Based on Expert Scoring Hierarchical Analysis", Geotechnical Investigation \& Surveying, pp.42-45,2002.

[7] XU Zeshui, "Study on Methods for Multiple Attribute Decision Making Under Some Situations", School of Economics \& Management, Southeast University, pp.12-73,2002. 